\title{
The analysis of competitive strategies from the perspective of small and medium enterprises
}

\author{
Nebojša Pavlović ${ }^{1 *}$, Irena Čelić ${ }^{1}$ \\ ${ }^{1}$ University of Kragujevac, Faculty of Hotel Management and Tourism in Vrnjačka Banja, \\ Serbia
}

\begin{abstract}
In contemporary conditions of the economy, the small and medium-sized enterprises (SME) face numerou s challenges because of the constant changes, which create both new threats and opportunities. The competition is fierce in the market - only those with clear plans and strategies will manage successfulbusinesses. The companies rely ing on no strategy or using a little bit of everything cannot be expected to thrive. The paper will explain in more depth the particularities and ways of org anizing an entrepreneurship activity in the SMEs. Furthermore, it would des cribe competitive strategies and their positioning within an SME. The aim of this study is to explore competitive strateg ies and ways of their application in the SME.
\end{abstract}

Keywords: SME, competition, differentiation, cost advantage JEL classification: L26, M21, M31

\section{Analiza konkurentskih strategija iz perspektive malih i srednjih preduzeća}

Sažetak: Mala i srednja preduzeća (MSP) u uslovima savremene ekonomiije nailaze na brojne teškoće u poslovanju usled svakodnevnih promena, koje stvaraju nove pretnje išanse. Izuzetno je izražena konkurentnost na tržištu, uspešno posluju samo ona preduzeća koja imaju jasne planove is trategije. Kompanije koje ne koriste ni jednu strategiju ili koris te od svih strategija po malo, ne mogu se nadati uspehu u pos lovanju. U radu će detaljnije biti objašnjene specifičnosti i načini organizovanja preduzetničkih aktivnosti u sektoru malih i srednjih preduzeća. Takođe, biće opisane konkurentske strategije i njihov značaj za pozicioniranje MSP-a. Cilj rada je ispitivanje konkurentskih strategija i načina njihove primene u sektoru MSP-a.

Ključne reči: MSP, konkurencija, diferencijacija, troškovna prednost JEL klasifik acija: L26, M21, M31

\section{Introduction}

Companies fromSME sector havebeen present in the developed countries for a long time. They play a major role in the transition process of the developing countries. These enterprises are also important for the employment of new workers and the stabilization of the

\footnotetext{
* racapn@gmail.com

** The paper is the result of the research within the project 179066, funded by the Ministry of Education, Science and Technological Development of the Republic of Serbia.
} 
underdeveloped countries. Once SMEs are es tablished, the priv ate sector is privatized and liberalized. This is what happens when the development of SMEs relies on the positive experience of the EU member states and the countries in transition (Zrnić, 2014).

Between 2012 and 2015, Serbia recorded a constant increase in the number of SME. In Serbia, the year 2016 was declared as the year of entrepreneurship (Njegomir et al., 2017). Also, in recent years, there has been an increasing emphasis on women's entrepreneurs hip in Serbia (Krasavac et al., 2019). Entrepreneurial ventures gave a great contribution to competitiveness increase (Aničić et al., 2019). The SME sector of Serbia differentiates from the one in the European Union. The characteristic of the Serbian sector is the fact that there are more job losses than in the European Union. In 2013, the value-added tax was $18 \%$ lower than it was in 2011.The value-added tax increased by $8.6 \%$ in 2014 . We can ascribe these performances of the SME to the changing business environment, characterized by an unstable financial sector and low demand.

Currently, the Serbian economy and industry are characterized by the technological and economic decay of most installed capacities, and dominant presence of traditional manufacturing (standardized products). In addition, Serbian economy includes exported goods which do notfeature any recognizable product aimed at prospective buyers in the past. Those products were marketed to a limited number of des tinations (Zrnić, 2014). Companies in Serbia are not competitive abroad (Miletić et al., 2018).

This paper will present the ways of implementing competitiveness strategies in the SME sector. In order to achieve this, experts resort to generic strategies .

\section{The unique parts of entrepreneurship in modern industry}

Today, popularity awaits anyone who has an entrepreneurial spirit. The modern world is characterized by changes. Every day we hear about the changes in politics, development of the new economic models and instruments, as well as the advantages of the modern technology. These changes "feed off each other" and they take impact on a global character. One of the key changes in the modern world is the increasing sensitivity and responsibility of the business. The firms have to constantly upgrade their products and services. This is what the consumers expect from them. If the companies want to survive in the market, they have to act fast, and be both agile and innovative. At the same time, changes can be perceived as both business opportunities and problems. Business opportunities are new chances which might lead to a better future (Beganović, 2015).

\subsection{Entrepreneurial organization in modern economy}

Today, the modern economic structures are characterized by fast, dynamic, and extremely complex changes that exert a signific ant impact on the individual's behavior. They also determine the development of an organizational structure. Economy as we know it is changing every day and adjusting to the society. New products make changes among consumers in their habits, tastes, and other trends (Avlijaš \& Avlijaš, 2013).

According to Škrbić et al. (2019) entrepreneurship is a crucial element of competitiveness. Working on a new venture is a part of the entrepreneurial process which encompas ses more than just problem-solving. An entrepreneur finds, as sesses, and develops an opportunity des pite the forces that prevent themfrom creating something new. According to His rich et al. (2011) "the entrepreneurial process consists of four phases - identifying and evaluating a new opportunity, developing a business plan, securing the required resources, and managing the new company" (p. 9). Although the phases are sequential, the entrepreneur does not 
approach themseparately. They cannot approach one phase without det ermining what all phases will entail. For instance, in order for the entrepreneur to successfully identify and evaluate an opportunity (1st phase), they have to know what kind of business they will run at the end (4th phase) (His rich et al., 2011).

The idea is at the core of every business opportunity (Ćiric et al., 2018). An entrepreneur makes room for a new venture by identifying the opportunity. It is an arduous task. The basic goal of this step is to define the criteria which will be used to measure the quality of the business opportunity. Here, the entrepreneur identifies theopportunity and develops a vision. If they do not create the vision, then the new idea is just a dream. This step can take a while to complete because it requires one to come up with the pricing and selling strategies (Stefanović, 2005). Busines s opportunities do not arise all of a sudden. Namely, they occur as a consequence of the entrepreneur's devotion to and consideration of the venture. Sometimes they arise when the entrepreneur forms the mechanis $m$ for identifying chances (Avlijaš \& Avlijaš, 2013). For example, the entrepreneur can inquire if someone uses a product which they think does not satisfy the primary purpose. This type of a pers on always thinks about the needs and looks for a chance to create a new product. Another entrepreneur overlooks as their children or cousins play - this is their search for a new venture in the toy making industry. The members of a distribution channel can accurately detect the needs of consumers because of their close contact with them (Stefanović, 2005).

Opportunity becomes the propulsive fuel for creating a new project (Pavlović \& Krstić, 2016). It is necessary for a business opportunity to be carefully considered and assessed regardless whether it came to be because of the comments from consumers, business consultants, and members of the dis tribution channel or technical staff (Stefanović, 2005). When we check business ideas, all the time we look for arguments that are for and against turning an idea into a real business (Ćiric et al., 2018). The opportunity needs to be compatible with the pers onal skills and goals of the entrepreneur (Stefanović, 2005).

Regardless of the amount of the devoted effort, one of the decisions is the selection of the legal entity. According to Avlijaš and Avlijaš (2017) "the legal entities of a company are entrepreneur, partnership company, limited partnership, limited liability company, and joint stock company" (p. 12). It should als obe established based on the short- or long-term needs of a company. This is a long phase of the entrepreneurial process. An entrepreneur usually does nothave any experience in how to devise a business plan or find any adequate resources for its development. A good business plan is a key for the development of an opportunity. It is also es sential in the process of finding and obtaining the needed resources. This will lead to the successful management of the venture (Buble, 2006). A business plan is similar to a road map (Pavlović \& Krstić, 2016). It shows the straight path of movementin the business.

Once armed with a good business plan, the next challenge is to focus on the needed resources and their procurement. The entrepreneur has to determine which resources are required in order to put theirplan into action (Buble, 2006). Access to finance is a much broader is sue than is generally observed (Bobić, 2017). Some of the ways of financing include private roles, foreign direct inves tment, borrowing base financing and the sale of the stocks of a firm. When it comes to the sale of the stocks of a firm, one should determine which stocks to sell, which percentage will be sold and what will be the stock price. It is important here to consider riskfactors. The needed resources should be secured in a timely manner. In this way, the entrepreneur keeps the ownership and control of their venture - especially in the beginning phase (Buble, 2006). The structure and volume of funds invested in a business depend on the projected results (Ćirić et al., 2018). The entrepreneurs should plan and decide financing and accounting because understanding these two things contributes to their success. This specifically refers to the process of understanding and analyzing the financial 
reports and budget, and setting the cash flow. One should implement the appropriate control systems in order to determine and solve problems quickly. A large number of entrepreneurs have a lot of issues while managing a firm they created (Buble, 2006). Also, there may be problems in the functioning of the company due to indebtedness, illiquidity, outdated technology (Kovačević, 2018).

\subsection{The factors affecting the competitiveness of entrepreneurship in modern industry}

The analysis of the environment is important in strategic planning. This is especially so because the environment in which the firms are located go through turbulent phases. They occur because of numerous factors and their interrelationships. Keeping a permanent track of the changes and trends and timely adjusting to them are imperative in modern business. In strategic planning, the termenvironment is used differently. For instance, in his definition, Zrnić (2014) includes all factors which are brought about independently of the manager's activities in a firm. This includes both internal and external forces (Zrnić, 2014). As an example, we take only those factors which are important for every level (Unković, 2014):

- Internal environment includes interactive relationship of interdependence between marketing and other activities of management (production, finance, employees, research, and development).

- Microenvironment, as a second level, consists of the factors which impact the marketing management and which are beyond the organizational boundaries. Those are competition, distribution, suppliers, customers, external marketing services, and public.

- Macro environment: On this level, the individual org anization almost has no impact on the factors. They are social and cultural environment, legal, economic, technological, and physical environment. Any of them can influence the marketing strategy, so it is important to follow their changes and trends.

In order for the environment as sessment system to be efficient, it has to include the activities such as identification, prediction, and assessment (Unković, 2014). Jain (1985) suggests six important steps in the assessment system:

1. One should know the trends of every key factor of the environment which was previously identified;

2. The most relevant trends should be defined and then researched in more detail;

3. It is crucial to determine the possible impact of the chosen trends in the modern products and market, including their possibilities and dangers;

4. Predicting the future movement of trends;

5. Analyzing the further possible effects of the trends in the future movement of products and market:

a) Assuming nothing happens and

b) That one reacts to the trends.

6. The last step is the assessment of the implication of the previous analysis in regards to the strategic decision making.

\section{Competitive strategies}

In the fight for greater market share, organizations can implement specific strategies (Ognjanović, 2015). Sometimes a firm's profitability can be modest, regardless of the fact that that industry does not have the desired structure. Even then, it is said that this firm, which independently achieves the position in the market, has a chance to have a high profitability (Porter, 2007). A firm can sustain if it attains advantage on the market compared 
to its competitors (Vrdoljak-Raguž \& Tolušić, 2012). The most important requirement for long-termabove-average results is a sustainable competitive economy. Low expenditure and differentiation are the two variants of the competitive advantage that the company can have on the market. The managers have a chance to choose for specific generic strategies. Porter writes that the generic strategies are cost leadership, differentiation, and focus. By applying the focus strategy, we can decide whether we want to focu on the spending or differentiation (Porter, 2007). These strategies we call "generic" because all businesses and branches can use them (Vukosav, 2016).

Competitive advantage is a dynamic concept (Milosavljević, 2002), and it can be made in different ways (Stanković, 2018). Each strategy entails that a company decides which competitive variant it will apply. A firm's goal is to have an advantage when compared to its competitors. The focus strategy strives to achieve an advantage in a narrow market. Companies go through different activities when applying the generic strategies. They depend on the industry in which a company is operating (Porter, 2007).

\subsection{Cost leadership}

When applying cost leadership, a firm sets out to become the low-cost producer in its industry. This strategy enables a firm to operate in many industry segments. Additionally, it permits a firm to work in a larger number of related industries, which impacts thecreation of the cost advantage. A firm can achieve cost leadership in many ways. For example, it can apply the economy of scale in its business or use some technology patents. If we obs erve the production of TVs, cost advantage requires amortization of R\&D costs, achieved through efficient production capacity, low-cost design, automated assembly and global business. On the other hand, if we examine the service ind ustry, this strategy would demand a firm to have both cheap labor and low expenditure. In addition, it would have to include a larger number of employees. In order to achievecost leaders hip, a company has to produce and offer the standard products and services on the market (Milačić, 2006). The reasons for maintaining low-cost strategy are (Shekhar, 2010):

- To attract more customers;

- To retain existing customers;

- To gain the maximum market share from the competitors;

- To earn a high profit margin for maximization of profit;

- To restrain competitors in the market.

The company implements this strategy when the product is on the maturity stage (Džanković-Jerebičanin, 2014). A company which successfully implements this strategy will be able to determine the prices in a particular industry. This refers to the average prices of the products and services or the prices that are close to being average. Cost leaders hip will bring a higher profit for a firm when the prices of the products or services are lower or the same as the ones offered by its directcompetitors on the market. It is important not to forget about the other strategy - the differentiation strategy. The products and services of a firm can be characterized as uncompetitive. In this case, the managers would have to lower the prices of the products/services, comparing them to those of their competitors. Cost leadership would achieve worse results and removeall of the advantages a firm gained. The example of the companies that found themselves in this situation would be the watch manufacturer Texas Instruments and Northwest Airlines. The first company could not overcome the is sues and it left the industry. However, the second one understood what was happening and succeeded in making its services competitiveby investing in marketing (Milačić, 2006). An example of a successfully implemented cost leadership strategy is Hyundai Company. It sells the i10 model at low prices and retains the product quality that is in the top class of city cars 
(Vrdoljak-Raguž \& Tolušić, 2012). This strategy can also be applied in hospitality and tourism companies. That company has to look out for the risk of impossibility to permanently keep prices down (Vukosav, 2016).

\subsection{Differentiation}

In the differentiation strategy, a firm seeks to be unique in the eyes of their buyers. It selects one or more attributes of the products/services and tries to sustain in the market by satisfying the needs. By implementing this strategy, the company gains a benefit - the premiumprice of its products (Porter, 2007). If a company follows a differentiation strategy, it will also have a wide variety of product lines (Kotler, 2010). By using this strategy, the company achieves a unique position in its business segment (Albijanić, 2013).

According to Senić and Milojević (2015), buyers are very valuable assets of the enterprises. Implementing a differentiation strategy is the best way to meet customer needs, tastes and preferences (Shekhar, 2010). The implementation of a differentiation strategy has a positive effect on the performance of the company (Kaya, 2015). Differentiation can be based on the products as well. The company Caterpillar Tractor is the construction equipment manufacturer. The differentiation strategy of their products is based on their longevity. The company alsotakes care of its machines and has a good network of buyers. On the other hand, if we were to look at the cosmetic industry, we could see a completely different situation. They base the differentiation strategy on the product image (Porter, 2007). Mercedes-Benz Company is an example of successfully implemented differentiation strategies. Their S-Class model is differentiated by price, image, customer loyalty and product quality (Vrdoljak-Raguž \& Tolušić, 2012).

During the implementation of this strategy, costs must be controlled (Kotler, 2010). A company can get numerous benefits if it uses and saves the product differentiation in an adequate manner. It can achieve excellent results if it has the adequate premium price of the products/services. Therefore, it is imperative for a company to always accomplish its adequate premium price (Porter, 2007).

It is significant to mention Porter (1980), who differentiate four differentiation strategies based on:(i) innovation, (ii) services, (iii) market, and (iv) quality. This strategy is extremely relevant for the SMEs, because it is difficult for them to apply cost leadership strategy (Katić, 2013).

\section{Sustainability of generic strategies}

Whichever generic strategy applied, it has to be sustainable as well. If not, the planned results, which would be above the average, will not be obtained. The sustainability strategy involves the firm setting up some barriers in order to stop its competitors. In addition, a firm would always need to be ready to improve its position (Porter, 2007). Sustainability can only be achieved if the company is able to base its advantage on a large number of elements (Arsenović \& Kovačević, 2015).

Sustainable advantage is possible in industries where businesses use multiple different strategies (Milos avljević, 2002). In some industries, industry structure or the strategies of competitors eliminate the possibility of achieving one or more generic strategies. Occas ionally, a firm cannot go through cost leadership because it is applied by several other firms operating in the same industry. On the other hand, the focus strategy is not applicable if there is a small number of segments in one industry (Porter, 2007). 


\section{The significance of competitive strategies for the positioning of SMEs}

Strategic orientation is the only solution to many internal problems and weaknesses of SMEs (Lazarević-Moravčević et al., 2018). According to Porter, managers opt for a strategy by ass essing how the company creates value. In other words, they examine how they achieve competitive advantage (with the help of differentiation or cost leadership) and how it determines its target scope (either focus or industry-wise). The author identifies threegeneric strategies achieving competitive advantage. They are recognizable both in literature and business (Krstić, 2009):

1. Cost Leadership - a firm is a low-cost producer, offering products at a cheaper price than competitors;

2. Differentiation strategy - a firm gains consumers' loyalty and expands the possibility for the price policy. It achieves this because of the physical and psychological difference of its products compared to competitors;

3. Focus strategy - company focuses their business on one or more attractive seg ments on the market.

Competitive advantage is achieved differently with each of these generic strategies (Robbins \& Judge, 2013). Companies that implement cost leadership have the lowest expenditures in an indus try. Differentiation strategy means that company has some unique characteris tics on the market along some dimensions which buyers value. They reward a company by accepting the premiumprice. Differentiation can have as its basis a product/service. It can also have the marketing approach of a company, etc. Company using the focus strategy selects one or more segments in the industry and focuses on satis fying its/their specific needs (Krstić, 2009). If an SME wants to successfully implement a cost leadership strategy, it should havetightcostcontrol, keep pace with changes in technology, etc. For successful implementation of differentiation strategy an SME must to build a brand image, rely on specialist skills, oversee market changes (Avlijaš, 2008). According to Porter, many companies can decide to apply the same strategy. If the basis of that strategy is the same, then the competition can escalate. This competition would not have a positive influence on the companies' profits (Porter, 2007).

The research study often claims that the owners/managers of SMEs do not apply any strategy. SMEs have strategies, but they are less formal. Additionally, they focus on specific activities or competitive tactics carried out daily within a firm (Katić, 2013). SMEs can offer to cus tomers standardized products/services. In this situation, the differentiation strategy is most often based on price, quality, functions, sales method, etc. (Avlijaš, 2008). A study conducted in Kenya shows that most SMEs successfully implement a differentiation strategy. That study shows that differentiation can be achieved by offering a wide range of products, offering a quality product, quickly res olving customer complaints, hiring modest employees, setting good prices (Njuguna et al., 2015). In addition, differentiation in SMEs can be achieved by introducing innovation, flexibility and creating services that are tailored to the customer's personality (Avlijaš, 2008).

While creating its position on the market, a company should adjust its strategic abilities and advantages and use themtogether with the chances from the external environment (Popes ku \& Jovanov, 2010). The company als o can be in "Stuck in the middle" position. "Stuck in the middle" means that a company did not devise any adequate strategy in its competitive strategic plan. A company will often think that it can use all strategies, which can lead to failure. This strategic position results in a below-average performance. We should not expect that a firm can be successful in all segments. According to Porter, a firm can be success ful if it chooses only one generic strategy (Krstić, 2009). 
Business owners' personal goals mustalways be reflected in the SMEstrategy (Ožegović \& Pavlović, 2012). A competitive SMEstrategy must be formed and adapted to the particular businesssituation (Avlijaš, 2008). In SME sector, the managers are not involved enough and are disinterested in the strategy and the planning process. This happens either because of the lack of time or resources. This is why they focus on the operational activities. Among the SMEs, the strategy is usually implicit, informal and intuitive (Katić, 2013).

\section{Conclusion}

It is the most important that SMEs in Serbia understand the competitive strategies because without relying on any, they will manage an unsuccessful business. Their business will suffer if they also apply insufficiently researched, analyzed, and known strategy. In the modern world of changes, companies fight for their place in the market as well as for expansion. In order to be stable, SMEenterprises have to apply clear competitive strategies and conduct a long-term planning. Cost leadership might not be suitable for SME compared to the differentiation strategy because of their financial capabilities.

Based on the above literature, it can be concluded that competitive s trategies in SMEs can be applied in different ways. A costleadership strategy can be successfully implemented with strict costcontrol and monitoring of technological changes (Avlijaš, 2008). Observing the researches of Avlijaš (2008) and Njuguna et al. (2015) it can be concluded that differentiation strategy can be applied by introducing innovations, flexibility and creating customized customer service, then by offering a wide range of products, offering a quality product, quickly resolving customer complaints, modest employee behavior, favorable prices.

In the strategic development process, thecompanies within theSMEfind that the activity of performance as sessment is important. SMEs often do notuse any strategic planning and do not really understand all factors which are key to their success (Zrnić, 2014). However, it is the most important thing that all factors, both tangible and intangible, be included in the analys is of a firm's performance. Systems for measuring performances favours the creation of a learning process as well as an agreement for the improvement of certain processes.

\section{References}

1. Albijanić, M. (2013). Strategijski menadžment [Strategic management]. Beograd: Univerzitet Singidunum.

2. Aničić, J., Aničić, D., \& Kvrgić, G. (2019). Sustainable growth and regional competitiveness of Serbian economy. Ekonomika, 65(2), 65-74. https://doi.org/10.5937/ekonomika1902065A

3. Arsenović, V., \& Kovačević, Ž. (2015). Formulisanje strategije preduzeća kao analitički proces: domet Porterovog pozicionis tičkog pristupa [Corporate strategy formulation as an analytical process: The reach of Porter's positioning approach]. SVAROG, 11, 132149.

4. Avlijaš, R. (2008). Preduzetništvo $i$ menadžment malih $i$ srednjih preduzeća [Entrepreneurship and management of small and medium enterprises]. Beograd: Univerzitet Singidunum.

5. Avlijaš, R., \& Avlijaš, G. (2013). Preduzetništvo [Entrepreneurship]. Beograd: Univerzitet Singidunum.

6. Avlijaš, R., \& Avlijaš, G. (2017). Preduzetništvo [Entrepreneurship]. Beograd: Univerzitet Singidunum. 
7. Beganović, A. (2015). Razvojinovativnostii konkurentostipreduzeća [The development of innovation and competitiveness of enterprises] (Unpublished doctoral thes is). Sremska Kamenica: Fakultet pos lovne ekonomije.

8. Bobić, D. (2017). Preduzetništvo mladih u Srbiji-Mapiranje preprekaza preduzetništvo mladih [Youth entrepreneurship in Serbia - Mapping barriers to youth entrepreneurship]. Beograd: Nemačka saradnja \& CEVES.

9. Buble, M. (2006). Osnove menadžmenta [Fundamentals of management]. Zagreb: Sinergija nakladništvo.

10. Ćirić, D., Stančetić, M., Topo, M., \& Šešlija, N. (2018). Šta sve čini avanturu zvanu preduzetništvo? [What makes an adventure called entrepreneurship?] Novi Sad: EduNS.

11. Džanković-Jerebičanin, A. (2014). Vrste strategija imoguće strategijske opcije [Types of possible strategies and strategic options]. Ekonomski izazovi, 3(6), 137-153.

12. Hisrich, R. D., Peters, M. P., \& Sheherd, D. A. (2011). Poduzetništvo [Entrepreneurship]. Zagreb: MATE d.o.o.

13. Jain, C. (1985). Marketing planning and strategy. Ohio, Mason: South Western Publishing Co.

14. Katić, A. (2013). Razvojmodela za ocenu konkurentnosti u društvu zasnovanom na znanju [Development of a model for assessing competitiveness in a knowledge-based society] (Unpublished doctoral thesis). Novi Sad: Fakultet tehničkih nauka.

15. Kaya, N. (2015). Corporate entrepreneurship, generic competitive strategies, and firm performance in small and medium-sized enterprises. Procedia-Social and Behavioral Sciences, 207, 662-668. https://doi.org/10.1016/j.sbspro.2015.10.136

16. Kotler, M. (2010). Strategijskimenadžment nadelu. [Strategic management in action]. Beograd: Data Status.

17. Kovačević, S. (2018). The differences in the way of management of business companies in Republic of Serbia and the European Union and the possibilities of its abuse. Pravo teorija i praksa, 35(7-9), 29-40.

18. Krasavac, B. C., Karamata, E., \& Djordjevic, V. (2019). Innovative potential of environmentally motivated female entrepreneurship for sustainable development in the Republic of Serbia. Economics of Agriculture, 66(3), 721-735. https://doi.org/10.5937/ekoPolj1903721C

19. Krstić, B. (2009). Intelektualnikapitali konkurentnost preduzeća [Intellectual capital and competitiveness of enterprises]. Niš: Ekonomski fakultet.

20. Lazarević-Moravčević, M., Erić, D., \& Kamenković, S. (2018). The impact of business environment on the performance of the SME sector in Serbia. Poslovna ekonomija, 12(1), 33-53. https://doi.org/10.5937/poseko13-17281

21. Milačić, Lj. (2006). Konkurentnost u troškovima kao generička strategija [Cost competitiveness as a generic strategy] (Unpublished doctoral thesis). Novi Sad: Ekonoms ki fakultet.

22. Miletić, V., Miletić, S., \& Ćurčić, N. (2018). Organization's profitable business conduct as the outcome of advancing competitiveness by the CRM concept. Anali Ekonomskog fakulteta u Subotici, 54(40), 33-48. https://doi.org/10.5937/AnEkSub1840033M

23. Milosavljević, M. (2002). Konkurentska prednosti dinamika konkurencije [Competitive advantage and competitive dynamics]. Marketing, 33(3-4), 11-116.

24. Njegomir, V., Pejanović, L., \& Keković, Z. (2017). Agricultural entrepreneurship, environmental protection and insurance. Economics of Agriculture, 64(3), 1035-1047. https://doi.org/10.5937/ekoPolj1703035N

25. Njuguna, V. N., Ochieng, I., \& Odida, A. (2015). The contribution of differentiation strategy adopted by SMEs to their competitive advantage: A case study of small and medium sized enterprises in Nyahururu, Kenya. European Journal of Business and Management, 7(29), 125-130. 
26. Ognjanović, J. (2015). Analiza konkurenata i strategije konkurentskog nadmetanja [Competitor analy sis and competitive strategies]. Menadžment u hotelijerstvu i turizmuHotel and Tourism Management, 3(2), 80-88.

27. Ožegović, L., \& Pavlović, N. (2012). Menadžment malih i srednjih preduzeća nosilac razvoja privrede [Management of small and medium size enterprises as a carrier of economic growth]. Škola biznisa, 12(1), 74-84.

28. Pavlović, N., \& Krstić, J. (2016). Preduzetništvo i menadžment [Entrepreneurship and management]. Vrnjačka Banja: Fakultet za hotelijerstvo i turizam u Vrnjačkoj Banji.

29. Popesku, J., \& Jovanov, Z. (2010). Pozicioniranje kao sredstvo za postizanje održive konkurentske prednosti turističkih destinacija [Positioning as a means of achieving sustainable competitive advantage of tourist destinations]. Acta Facultatis Medicae Naissensis, 27(4), 523-530.

30. Porter, M. (2007). Konkurentska prednost: ostvarivanje i očuvanje vrhunskih poslovnih rezultata [Competitive advantage: achieving and maintaining outstanding business results]. Novi Sad: ASEE.

31. Porter, M. E. (1980). Competitive strategy: Techniques for analyzing industries and competitors. New York: Free Press.

32. Robbins, S., \& Judge, T. (2013). Organizational behavior. London: Pearson.

33. Senić, R., \& Milojević, S. (2015). Recovering lost customers. Menadžment u hotelijerstvu i turizmu - Hotel and Tourism Management, 3(2), 25-40.

34. Shekhar, G. S. (2010). Business policy and strategic management. New Delhi: I. K. International Publishing House Pvt Ltd.

35. Stanković, J. (2018). Green marketing and green product. Economics of Sustainable Development, 2(2), 37-46.

36. Stefanović, V. (2005). Preduzetnički menadžment [Entrepreneurial management]. Zaječar: Fakultet za menadžment.

37. Škrbić, I. M., Mišković, I. D., Milošević, S. M., \& Nešić, M. (2019). Preduzetnički modeli u funkciji održivog turizma [Entrepreneur models in function of sustainable touris m]. Poslovna ekonomija, 13(1), 81-99. http://doi.org/10.5937/poseko 15-19527

38. Unković, M. (2014). Konkurentnost privrede [Competitiveness of the economy]. Beograd: HERA edu.

39. Vrdoljak-Raguž, I., \& Tolušić, M. (2012). Implementacija Porterovih generičkih strategija i postizanje konkurentskih prednosti na primjeru automobilske industrije [Implementation of Porter's generic business strategies and achieving competitive advantage in the automobile industry]. Ekonomsk a misao i praksa, 1, 381-398.

40. Vukosav, S. (2016). Strategijski menadžment ugostiteljsko-turističkih preduzeća [Strategic management of hospitality and tourism companies]. Novi Sad: Prirodno matematički fakultet, Departman za geografiju, turizam i hotelijerstvo.

41. Zrnić, D. (2014). Razvoj modela konkurentnosti malih i srednjih preduzeća u tranzicionim uslovima [Development of the model of competitiveness of small and medium-sized enterprises in transition conditions] (Unpublished doctoral thesis). Novi Sad: Fakultet tehničkih nauka. 